\title{
Romanticism in Context: Shelley's and Keats's Verse and Prose: Keats's Letters and Ode to a Nightingale, Shelley's Defense of Poetry and Skylark
}

\author{
Walid A. Zaiter* \\ Department of Languages and Translation, Taibah University, Saudi Arabia
}

Corresponding Author: Walid A. Zaiter, E-mail: walid241960@yahoo.com

\section{ARTICLE INFO} \\ Article history \\ Received: April 28, 2018 \\ Accepted: June 20, 2018 \\ Published: July 31, 2018 \\ Volume: 6 Issue: 3 \\ Conflicts of interest: None \\ Funding: None

\section{Keywords:} \\ Romanticism in Context, \\ Imagination, \\ Nature, \\ Verse, \\ Prose, \\ Keats, \\ Shelley
}

\begin{abstract}
This paper argues it is probably unavoidable perceiving the works of Shelley and Keats without putting these works in the context of the age and in the context of Romanticism. On the whole the selected pieces of prose and verse of the poets represent their postulations in an era which witnessed great revolutions, political and industrial bringing about new trends in literature and in society. From the personal perspective of the two poets, the birds in the poems represent ideals reflecting the treatment of imagination, nature and ideology of their time and their individual experience, knowledge of the world and of prosody. Thus the treatment of this topic as such opens an old and new interpretation of the poets' work since the topics in their poetry can apply to their age and ours.
\end{abstract}

\section{INTRODUCTION}

Stephen Prickett in his introduction to The Context of English Literature: The Romantics, defines Romanticism as "characterizing a distinctive age, or even a movement... The period between 1770 and 1830 had, or was believed to have, an internal consistency and rationale uniquely its own"(1). He as well traces down the "original usage of the word "romantic "which goes back to1656. He found that the word romantic and its forms indicate "the suggestions of fable, fairy tale and even dream were never very far from the word[romantic] throughout most of the eighteenth century(1). Prickett asserts that the word [romantic] was first used by Goethe and Schiller at the beginning of the nineteenth century. Prickett suggests that Schiller, then, saw in Romanticism "union of opposites or discordant qualities. Like Schiller, Schlegel believed that Romanticism replaced classicism. Prickett suggests that the word romantic could apply to any writer from any age as long he or she maintains the qualities mentioned above. Therefore, it is not "difficult to see Aeschylus as romantic and Sophocles as classic." In England the Elizabethan was surely as much as a romantic age as was the end of the eighteenth century" (3). In the same vein Rene Wellek in "The Concept of Romanticism in Literary History" views Romanticism as " a new designation for poetry, opposed to the poetry of neoclassicism, and drawing its inspiration and models from the Middle Ages and the Renaissance"(4).Then along his essay he explicates the distinctive characteristics of romantic poets focusing on imagination, nature symbol and myth in their poetry.. However, each of the romantics treated these elements especially imagination distinctively. He states that Blake, Wordsworth, Coleridge and Keats did appear to share similar concepts in their lives, their art and in their attitude to their environment... Wordsworth and Coleridge... commonly used imagination to describe psychological activity, whereas for Blake and Keats the word carried a transcendent or visionary connotation..." (5). other elements which most romantics drew on in their poetry were religion, philosophy and politics."Literature was not an activity separate from politics, philosophy or religion". On these grounds Wordsworth, acquired poetry by means of politics and philosophy. So did Coleridge who was a political journalist, preacher and lecturer, philosopher, theologian and literary critic (5). Shelley and Keats followed their heels but Shelley went too far in 
his views regarding religion. In this context Jake Porter in his essay " Coleridge, Shelly, Keats, and God: The Romantic Poetics of Doubt" (2016) examines "a sampling of the writings of " these poets and "relate them to two disparate theological strands - natural religion and Deism"(1-2). Raymond Williams in Culture and Society (1958) sums up the subject matter of all the romantics versus other poets. "The Romantic Artist than the poets from Blake and Wordsworth to Shelley and Keats there have been few generations of creative writers more deeply interested and more involved in study and criticism of the society of their day"(30). Surprisingly, according to Seamus Perry in "Romanticism: The Brief History of a Concept" (1999) the "Romantics did not know that was what they were." It was the business of the critics of our age, who have categorized the romantics into lake School' (Wordsworth, Coleridge and Southey), the 'Demonic School' (most notoriously, Byron), the 'Cockney School' (Leigh Hunt and Keats)"(2). These aspects above mentioned are the criteria upon which Romanticism and the romantics must be taken into consideration to study any work of the romantics. They provide plausible interpretation for critics of the romantics in any age in accordance with new literary that appears in every age: Classicism, Romanticism, Modernism, etc. these interpretation will add to the canonical poets of Romanticism.

\section{ROMANTICISM IN ENGLAND AND FRANCE}

Since we cannot divorce Romanticism as a literary movement from other variables which affect the milieu of the age, one may wonder about the historical and political contexts in England between 1782 and 1832. This period witnessed the rise of Romanticism. Colin Brooks asserts that "Romantic England was an England of wars and rumors of war... Throughout the years 1782- 1832 the political system was under stress... it had to organize the fighting of the wars against France. It had to maintain public order whilst insisting upon individual responsibilities. (15-7). He concludes his main observations on the: The age was self-conscious, searching for its spirit. It was an age of transition... It was an age of paradox and contradiction... Class became an appropriate category for such arguments... The Industrial and the French Revolutions were separate phenomena: but they soon became, and still are, indissoluble in their consequences, threats and promises" (68-9). Thus most of the Romantics found inspiration in the French Revolution for its universal tenets of democracy, freedom and equality. "Romantic texts need to be understood with some sense of the historical circumstances within which they were produced"(Bygrave 15). David Duff in his essay "From Revolution to Romanticism: The Historical Context to 1800 " argues that one should "begin with the Romantics' own impressions about the historical forces that shaped their writings." He adds: "For William Hazlitt, author of a collection of essays actually entitled the Spirit of the Age (1825), there was no doubt that the central historical experience of his generation was the French Revolution" (23). This was evident in the writings of the romantics of both generations.

\section{ROMANTICISM, PHILOSOPHY, NATURE AND VALUES}

One may equally wonder about philosophical influence of John Lock on the Romantics since the movement was philosophical. T.J. Diffey in his essay "The Roots of Imagination: the philosophical context" affirms that "essentially Lockean empiricism and English Romanticism are at issue over two main questions: the nature of perception, and the nature of language and meaning. (166). Another component of Romanticism is nature which is totally different from that of the eighteenth century in that Prickett in an essay entitled "Romantic Literature" cites A. O. Lovejoy who "claims to have distinguished more than sixty separate meanings of the word nature, but the complexity of the word and its connotations are apparent" (211). Although Nature plays an important role as a source of inspiration to all the romantics, it has certain contexts in the poetry of Wordsworth, Coleridge Keats, and Shelley. It depends on the early and later poetry of each poet, which defines its influences on the Romantics, internally or externally. Since the scope of this paper is not on all the Romantics, but only on Shelley and Keats, then they will receive equal treatment or discussion, where they converge and diverge on nature, imagination and values. Porter sums up the beliefs of the two poets: "Shelley expressed the unknownability of ultimate reality, but it was Keats who was to take it further and express perhaps the highest flowering of the belief/doubt dialectic in Romantic poetry"(13). These aspects are found in some pieces of their prose and verse: Keats's Letters and Ode to a Nightingale, Shelley's Defense of poetry and Skylark. These works are formulations of thought and poetry.

\section{SHELLEY AND KEATS: IMAGINATION AND NATURE VERSUS ENLIGHTENMENT}

Peter J. Kitson in "Beyond the Enlightenment" argues: In The Defence of Poetry Shelley clearly distinguishes between the empirical reason from the higher imaginative powers of the mind." On this distinction the Romantics adopted and developed trends in Enlightenment philosophy" (40) with the aid of Kant's Philosophy. The same applies to "Keats's criticism of science's tendency to demystify the world"(41). Shelley's Defense of Poetry and Keats's Letters are canonical works that set a difference between the two poets and their poetry. Despite the fact that Shelley wrote his Defense of Poetry by reading the article entitled "The Four Ages of Poetry," Shelley remarkably voiced his postulations about the role and function of poets and poetry. Shelley defines poetry in terms of imagination, man, music (Æolian lyre). These elements are significant to read Shelley as a poet to see where his inspiration is triggered. According to Shelley poetry is created by imagination and man is theme of all poetry" the expression of the imagination: and poetry is connate with the origin of man. Man is an instrument over which a series of external and internal impressions are driven, like the alternations of an ever-changing wind over an Eolian lyre, which move it by their motion to ever-changing melody"(The Oxford Anthology o English Literature: 
"Defense of Poetry" 747). This is an open invitation to all poets that making poetry is as natural as music produced by the wind playing on the strings of Æolian lyre. By the same token anything in nature can trigger the imagination of a poet. Shelley's Skylark flies higher and higher to the extreme destination towards heaven. The bird stands for poetic creation and inspiration and freedom of thought not found in the previous age. No wonder that the French Revolution had impacted the second generation of the Romantics; its ideals of democracy and liberty of thought inspired them to create new expressions, which were unavailable to the preceding age. In the same vein poetry became religion and poets became prophets. Poets also became the builders of society in all walks of life. Shelley postulates that poets are" the institutors of laws, and the founders of civil society, and the inventors of the arts of life, and the teachers, who draw into a certain propinquity with the beautiful and the true that partial apprehension of the agencies of the invisible world which is called religion"("Defense of Poetry"748). This vision could not have formulated without the impact of the French Revolution which was a source of inspiration to the Romantics. David Simpson in "The French Revolution "places Shelley's Defense in context of its impact on poetry:

Shelley's 'Defense' makes the strongest of all Romantic cases for the social and historical powers of poetry (or literature), even if it is marked, as I have suggested, by critical qualifications and retractions. And indeed Shelley was the inheritor of a literary culture for which the disconnection of good literature from the ordinary constraints of time and place was already a sort of given (57).

Like Shelley, Keats in his letters postulates his tenets of poetry in prose and verse. These also were established over personal beliefs of the role and function of poetry and in the society, and over the impact of the older Romantics and the French Revolution on the Romantics.

\section{KEATS'S LETTERS AND HIS PRINCIPLES IN POETRY: BEAUTY AND IMAGINATION}

Like Shelley, Keats in his letters, especially the one addressed to his publisher John Taylor dated on February 27,1818 explicates his principles of poetry that it should surprise the reader of new thoughts and the making of poetry should come naturally to the poet, not as those in the previous age, who would put too much effort of writing a poem according to the rules and conventions of the age. Keats writes:" I think Poetry should surprise by a fine excess and not by Singularity--- it should strike the reader as a wording of his own highest thoughts, and appear almost a Remembrance." This is the basic role of poetry. Secondly, poetry should create a feeling of content on the reader and this is the beauty of poetry when "its touches of Beauty should never be halfway thereby making the reader breathless instead of content: the rise, the progress, the setting of imagery should like the Sun come natural to him--- shine over him." Finally, if Poetry comes not as naturally as the Leaves to a tree it had better not come at all "(Colvin 99). As for imagination, in a letter to Benjamin Bailey, Keats defines imagination in the context of beauty, passion in the sublime. These elements are necessary to trigger the imagination. Keats writes: What the imagination seizes as Beauty must be the truth whether it existed before or not, for I have the same idea of all our passions as of love: they are all, in their sublime, creative of essential Beauty (Colvin, Letter 41).

This definition of imagination is a key element among the Romantics but each gives it a special clouring according to his individual experience, the influence of other poets, knowledge of the world and prosody. For Keats, the product of poetic imagination is beauty and truth. Wellek in his above mentioned essay makes profound assertions concerning " theories of imagination" and " conception of nature" among the romantics. Each and every one of the Romantics shares some common grounds of treating imagination and nature in their poetry. However, Wellek claims that "all of them share a common objection to the mechanistic universe of the eighteenth century" and that "all romantic poets conceived of nature as an organic whole, on the analogue of man rather than a concourse of atoms - a nature that is not divorced from aesthetic values, which are just as real than the abstractions of science"(qtd in Prickett195-6). This is a basic difference between eighteenth century perception of nature and the Romantics' attack of it. A final note about the literary value of Keats's letters: "are pre-eminent in the genre, even unique. No other letters communicate so fully their author's temperament as his do, or display so bold an energy of mind in the confrontation of the problems of art and existence...,"(Bloom and Trilling 467).

\section{IMAGERY IN KEATS'S ODE TO A NIGHTINGALE AND SHELLEY'S SKYLARK}

John Creaser argues in "John Keats, Odes" (1999): Keats's odes are at their strongest - in to a Nightingale, To Autumn and a Grecian Urn..., separating or merging the selves in response to the flow of emotion and recollection." This reminds us of Wordsworth's definition of poetry. No wonder here that Keats is influenced by Wordsworth. Creaser suggests that these odes should be read "sequentially, much in these poems is the utterance of a speaker carried away by images of perfection"(239). Richard Harter Fogle expounds these images. Poetic imagery can fall into the following types:

Imagery of sensation, synaesthetic imagery, empathic imagery and concrete and abstract imagery... to establish the sensuous characteristics of the poetry of Shelley and of Keats as accurately and reliably as the conditions of such a study permit, I have analyzed 1722 lines from Keats and 2318 lines from Shelley, classifying all effective sense-images to be found in them under the headings visual, auditory, tactual, olfactory, gustatory, organic, kinesthetic and motor images" (29).

However, this paper shows that Keats's imagery ranges between sensual and mythological in a world of fairylands or old legends revisited by his imagination, but Shelley's imagery is philosophical and ideal. These qualities of their poetry can be traced in Keats's Ode to a Nightingale and Shelley's Skylark.

My heart aches, and a drowsy numbness pains My sense, as though of hemlock I had drunk, 
Or emptied some dull opiate to the drains

One minute past, and Lethe-wards had sunk:

'Tis not through envy of thy happy lot,

But being too happy in thine happiness, -

That thou, light-winged Dryad of the trees

In some melodious plot

Of beechen green, and shadows numberless,

Singest of summer in full-throated ease.(The Oxford Anthology of English Literature: Ode To a Nightingale, stanza I, lines 1-10)

Keats here is pouring his heart to the bird he is addressing; the bird is making him happy just listening to it sing happy melodies while sitting in nature; the picture of the bird is real; it evokes Keats's imagination to write poetry after feeling tranquil; it is an inspirational moment for creative imagination. Keats "invokes figures- pagan deity, nightingale, which could never respond. Invoking such ideals only emphasizes how unattainable or incommunicable they are"(Creaser 241). On the other hand, Shelley's Skylark is observed on flight to Heaven. The bird is there but it stands for the highest point that the imagination of the poet can reach

Hail to thee, blithe Spirit!

Bird thou never wert,

That from Heaven, or near it,

Pourest thy full heart

In profuse strains of unpremeditated art.

Higher still and higher

From the earth thou springest

Like a cloud of fire;

The blue deep thou wingest,

And singing still dost soar, and soaring ever singest.

And sing still dost soar, and soaring ever singest (The Oxford Anthology of English Literature: To a Skylark, lines 1-10)

Upon reading Keats's ode and Shelley's poem Fogle comes up with an interpretation which summarizes the two poems in the context of the poets' understanding of the world they depict. Shelley portrays the skylark as an emblem of his own theology, philosophy and poetic creation. However, Keats engulfs the bird with "disenchantment and desolation"(Creaser 245). Fogle finds a paradox in the imagery in the two poem, which is an aspect of the poetry of all Romantics; on one hand, the Romantics reveal their selves by addressing objects in nature they depict their ideals to entertain us with their beautiful imagery; on the other, they personify the deeper thought of the age, or the spirit of the age. Thus Fogle asserts

Paradoxically, Shelley the philosopher Monist is frequently dualistic in the composition of his visual images; he paints two pictures, one above the other, with a neutral zone of emptiness between. Keats, on the other hand, imparts to his scenes a pervading unity which intellectually he would have hesitated to impose upon the world... Shelley finds a fruitful source of poetic inspiration in the skylark, which soars vertically into the heavens until it disappears; Keats is impelled to write some of his finest verse by the nightingale, a dweller in trees, which does not venture far above the ground. Shelley as he apostrophizes the lark $(37-38,45)$.

\section{CONCLUSION}

To Sum up, Romanticism in context has been a criterion to interpret the poetry of the Romantics as a whole and the visual images in Keats's Ode to a Nightingale and Shelley's Skylark in particular. The imagery employed in their poems will not be perceived without Keats's tents or poetic principles discussed in his letters and odes and Shelley's Defence of Poetry and poems. Their poetic devices such as metaphors and personification of the birds in their poems have been employed to represent their inspiration and their theories of reflecting on the reality of their age at large and on their individual lives as poet in particular. Therefore, this comparative study of the two poets in particular and Romanticism as a whole has tackled some of their verse and prose in context to clarify their poetic tenets in theory and practice. Their poetry and theories of imagination have impacted the poetry of their age and probably for many generations to come. Romanticism has always been a major interest for many critics and students of literature around the world.

\section{REFERENCES}

Bloom, H. \& Trilling L. (1973). "Romantic Poetry and Prose." In Harold B. et al (eds) The Oxford Anthology of English Literature. Vol II. London: Oxford University Press.

Brooks, Colin. (1981). "England 1782- 1832: The Historical Context." In Stephen P. (ed), The Context of English Literature: The Romantics. London: Methuen and CO., 15- 69.

Bygrave, S. (2004).’Reading in History." Stephen B.(ed), In Romantic Writings. UK: The Open University. 15.

Colvin, S.(ed). (1891). Letters of John Keats to his Family and Friends. I Lonnrot: Macmilan and Co.https:// archive.org/stream/lettersofjohnkea00keatiala/lettersofjohnkea00keatiala_djvu.txt

Creaser, John (1999). "John Keats, Odes" "Romanticism: The Brief History of a Concept." in Duncan Wu (ed),UK: Blackwell Publishers Ltd.

Diffey, T. J. (1981). "The Roots of Imagination: the philosophical context." In Stephen P. (ed)., The Context of English Literature: The Romantics. London: Methuen and CO., 166

Duff in, David. (1999). "From Revolution to Romanticism: The Historical Context to 1800 "

"Romanticism: The Brief History of a Concept." in Duncan Wu (ed),UK: Blackwell Publishers Ltd.

Fogle, R H. (1949). The Imagery of Keats and Shelley: A Comparative Study. USA.: The University of North Carolina Press.,

Gilroy. H. (2010). Romantic Literature. Lebanon: Librarie du Liban Publishers.

Keats, John."Ode to a Nightingale. "Romantic Poetry and Prose." In Harold B. et al (eds) The Oxford Anthology of English Literature. Vol II. London: Oxford University Press 
Perry, Seamus. (1999).’Romanticism: The Brief History of a Concept." in Duncan Wu (ed),UK: Blackwell Publishers Ltd.

Porter, Jake. (2016). “ Coleridge, Shelly, Keats, and God: The Romantic Poetics of Doubt." Valley Humanities Review Spring 2016.

Prickett, S.(1981)." Introduction". The Context of English Literature: The Romantics. In Stephen P (ed), The Context of English Literature: The Romantics. London: Methuen and CO., 1-14

Prickett, S.(1981).’Romantic Literature.” In Stephen P.(ed), The Context of English Literature: The Romantics London: Methuen and CO., 220

Shelley, Percy Byshe. (1973)." A Defence of Poetry": The Literature of Knowledge and the Literature of Power.
Harold B. et al (eds) The Oxford Anthology of English Literature. Vol II. London: Oxford University Press.

Shelley, Percy Byshe. "To a Skylark" "Romantic Poetry and Prose.” Harold B. et al (eds) The Oxford Anthology of English Literature. Vol II. London: Oxford University Press. Simpson, D (2008). "The French Revolution." In H. B. Nisbet \& Claude R. (eds), The Cambridge History of Literary Criticism: Romanticism. Vol 5. Cambridge: Cambridge University Press, 57.

Wellek, R. (1981). The Concept of "Romanticism" in Literary History. Stephen P. (ed), Introduction. The Context of English Literature: The Romantics. London: Methuen and CO., 4-5.

Williams, R. (1958). "The Romantic Artist." Culture and Society: 1780 - 1950. New York: Harper and Row, 30. 